\title{
Physical Demarcation of Infrastructures and Making Detailed Physical Planning of Kabeza Site
}

\author{
Jean Pierre HABIYAREMYE ${ }^{\mathbf{1}}$ \\ ${ }^{1}$ Land Survey, GEO-SPATIAL SOLUTIONS LTD \\ Emails: habijp12@gmail.com/peter@geosltd.net
}

\begin{abstract}
Physical infrastructure is the basic physical structures required for an economy to function and survive. Rwanda, like other developing countries, its plans focus on the contribution to the solutions of the problems arising due to lack of well-planned local urban upgrading. The infrastructures that allow the access to the services of the population within the country must be maintained, constructed for better achievement of different goals at different levels from the Central Government up to the Sector level. This paper therefore examined the demarcation of the infrastructures and the detailed physical planning as a key component of urban development initiatives. The physical planning sets the boundaries with the purpose of having access to affordable infrastructure services for consumption purposes serves to improve household welfare and affordable housing and promoting a sustainable development for the benefit of the individual, for society and for future generation. The project was conducted in Kabeza Site, Eastern Province, Bugesera District, Ntarama Sector, Kanzenze Cell and Kabeza Village in Republic of Rwanda. Experimental and survey design have used in the assessment of existing physical features around and within the site by observation method using DGNSS Receivers, total stations, and also used participatory approach method. The study involved a detailed topographic survey of existing features on Kabeza site. An interview of stakeholders was conducted during the community meeting. Different software were used to analyze and re-plotting the physical planning. Findings show that the rapid rate of urbanization has led to a rise in informal settlements facing with the problems including lack of sufficient and adequate basic infrastructures. The paper therefore canvassed for immediate evolvement of physical plan that emphasis on keeping commitment to place, establishing the quality recreation areas and diversifying housing options. It was revealed that there is a need to establish a well planned roads, create a more vibrate village centre, light the whole village, establish a water system in the whole village, maintain and upgrade the greening village infrastructures, build community from assessment of the existing land use land cover, make and re-plot the new parcels within the site and to design details physical layout plan of that region. The study recommends the project implementers and partners, particularly the local government units overseeing the project site, to pay attention to the growing income disparity and the exclusion of the poorest from development process. Government should identify measures to minimize the interventions that impact negatively the life of wellbeing of the poor and women and also to minimize negative impacts on the environment.
\end{abstract}

Keywords: Infrastructures, land use, land cover, Local area plan, Physical planning, Replotting. 


\section{INTRODUCTION}

Physical planning is a key component of urban development initiatives and sets the boundaries with the purpose of having access to affordable infrastructure services for consumption purposes serves to improve household welfare, and affordable housing and promoting a sustainable development for the benefit of the individual, for society and for future generation. Making Physical Plan at any region with informal housing developed, it is better to do a local urban upgrading. This is defined as physical, social, economic, organizational, and environmental improvements undertaken cooperatively among citizens, community groups, businesses and local authorities to ensure sustained improvements in the quality of stay for individuals ${ }^{[10]}$.

The development of cities in Rwanda is very recent, and the rate of urbanization stands at about $18 \%$. Although, this rate is among the lowest in the world, the annual growth rate of the urban population of $4.5 \%$ far exceeds the worldwide average of $1.8 \%$. This monocephalic (sometimes called "megacity") situation highlights the imbalance between urban centers, towns and rural settlements within Rwanda. Challenges caused by rapid and unbalanced urbanization combined with scarcity of land are: the proliferation of unplanned urban growth, insufficient and unjustly distributed or inadequate housing and services for many residents, social instability, environmental degradation, and unsustainable, unhealthy cities ${ }^{[22]}$.

The main categories that define smart cities include the quality of the environment, energy, water and wastewater, transportation and traffic, information and communication systems, quality of life, government, economics, human resources, housing and land use, security, and emergency preparedness. Thus, the government of Rwanda has established a new urban and rural settlement sector to focus concerted and coordinated attention to this crucial problem; and hence this urbanization and rural settlement sector plan.

This paper has focused on detailed Physical planning of in Kabeza Site, Eastern Province, Bugesera District, Ntarama Sector, Kanzenze Cell and Kabeza Village in Republic of Rwanda. Bugesera district is one of 30 districts of the country located in Eastern Province. It covers a total surface area of $1337 \mathrm{Km}^{2}$. The district is composed of 15 Sectors, 72 Cells and 581 Villages with a total Population of 363,339 people where 177,404 are males and 185,935 are females ${ }^{[22]}$.

Bugesera is one of the Districts with unique tourist assets and potentials. Its natural endowments are not developed to foster a vibrant and competitive industry. However it has lots of potentials based on 9 lakes, rivers, geographical set up and culture. Bugesera is where the country's biggest airport is being constructed and still has relatively affordable land, which is increasingly becoming a strategic area for property developers.

This paper therefore examined the problems confronting informal settlement in Kabeza Village and proffer appropriate solutions to unravel them with the intention of maximizing the gains arising from the creation of detailed Physical Planning.

\section{MATERIALS AND METHOD}

\section{Site Location}

Kabeza Site is located around at $2.6 \mathrm{Km}$ from the Bridge of Akagera River which separate Kicukiro District and Bugesera District, in Ntarama Sector Kanzenze Cell in the Eastern Province and also located around $8 \mathrm{Km}$ from Bugesera District office. It is near the main road from Kigali to Nyamata and suitable for well-organized land use, nearest Kigali City especially Gahanga Sector where they will build Gahanga International Stadium, the different people will come to live on this site for doing their business around Gahanga new Kigali City Market, they will get water and electricity easily and other coming from Bugesera International Airport which is not very far from there. It is very safe region for the people from Kigali and others from Bugesera International Airport. Someone who will decide to live in that site, he/she will have access on all basic infrastructures like Water, Electricity, Education and Health care. Figure 1 indicates the location of the site in the district context. 


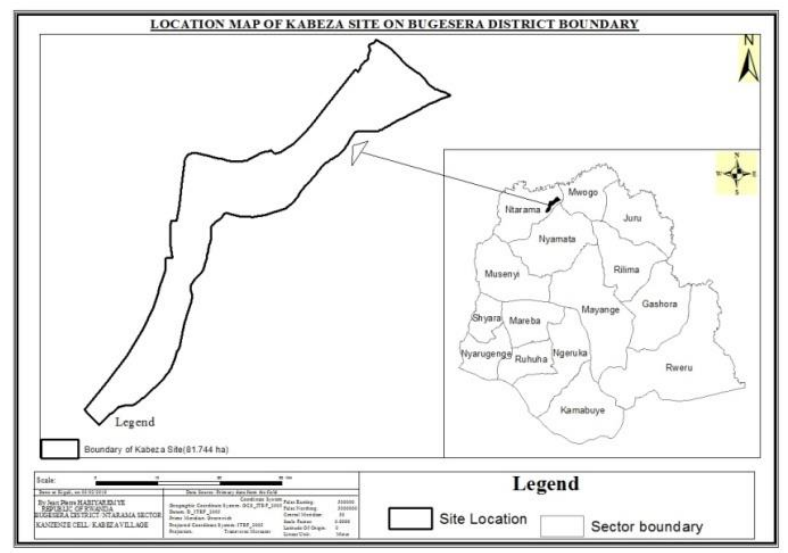

Figure 1. Site location

In general, a notable feature of this region is their disorderly nature. This is so because of informal settlement have grown on their own without any form of detailed physical plans, standards and urban design to guide them at their formation.

\section{Study design}

This article has used the experimental and survey design. Whereas was used in the assessment of existing physical features around and within the site by observation method using DGNSS Receivers, total stations, and also used participatory approach for involving of all stakeholders in the formulation of development policies and strategies and in the analysis, planning and local development plans, monitoring and evaluation of development activities through community meeting for explaining their contribution during make physical planning and gathering information of existing situation in the site from District level in other to get existing land use and information on land owners.

The primary and secondary sources of data have taken such as DGNSS and Total Station data, documentation, field observations, and the unstructured interview method.

\section{Source of data}

The study involved a detailed topographic survey of existing features on Kabeza site. It therefore entailed retrieval of historical background on the land usage with Kabeza site resident, review availability of basic infrastructures, inventory of the vehicles records in the same region, review of development control process among others. In addition, stakeholders in the built environment were interviewed during community meeting while additional data were sourced from published materials, journal articles, and internet among others. Data collection commenced in December 2018 and ended in July, 2019.

For analyzing, demonstrating the site plans, reploting and making detailed physical planning; ArcGIS10.3.1, Supermap iDesktop10i, AutoCAD \& CAVADIS 2007, STDM, Microsoft Office softwares have used and Arial photos and Google earth Professional.

\section{RESULTS AND DISCUSSION}

\section{Current situation in Kabeza site}

Most of existing parcels in this area have no access to roads and other basic infrastructures. The field visit revealed that some of the existing plots are bigger than $300 \mathrm{~m}^{2}$ and others are less than $300 \mathrm{~m}^{2}$ according to the land titles, however current use types is agriculture for some part and residential to another part.

\section{Topography and water drainage in Kabeza site}

The topography of Kabeza site is presented with difference in elevation of $87.12 \mathrm{~m}$ where the high level is $1439.64 \mathrm{~m}$ and minimum level is $1352.52 \mathrm{~m}$ with average on $1387.892 \mathrm{~m}$ of height. Referring to Robinson 


\section{(1) TECHNIUM}

Technium Vol. 2, Issue 4 pp.54-60 (2020)

ISSN: $2668-778 X$

www.techniumscience.com

and Bent Thagesen, (2004), this site Level terrain with 7 contours per Kilometer and Slope is presented in percentage between of $0 \%$ to $97 \%$ with average of $13.20 \%$ of slope in general.

Each road on this site must have drainage channel that will be different depending on the amount of water it will take but the dimension of these drainages vary from $0.60 \mathrm{~m}$ for tertiary drainage to $1 \mathrm{~m}$ for secondary drainage and $2 \mathrm{~m}$ for the main drainage channel. The rain water from the buildings will meet with rain water from different road in trapezoidal designed channel and taking place at the Kabeza wetland.

\section{Re-plotting the new parcels within Kabeza site}

A Replot of Lands happens when the lines of a parcel are redefined or when an existing parcel of land incorporates additional land into it without creating a new, independent parcel of land. But for this case a parcel has replotted and making new parcel (fig.2).

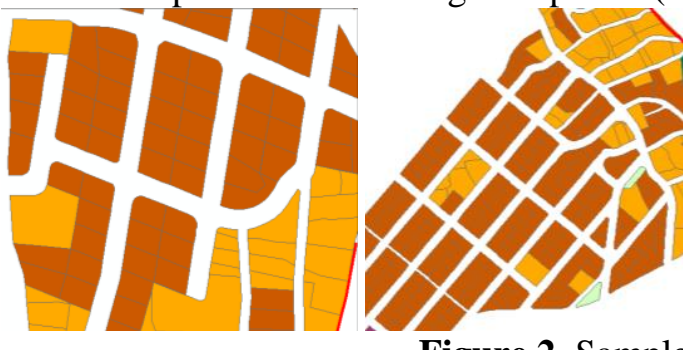

Figure 2. Sample on Layout plan of Kabeza Site

\section{Legend}

Replotted Parcels from Existing Designed New Parcels

\section{Designing detailed physical layout plan}

Kabeza site is designed by the researchers according to the needs of residents living there and the following zoning is highlighted in the plan: Residential, Roads, Commercial, Education, Green Space, Health Post, Recreation and Religious place.

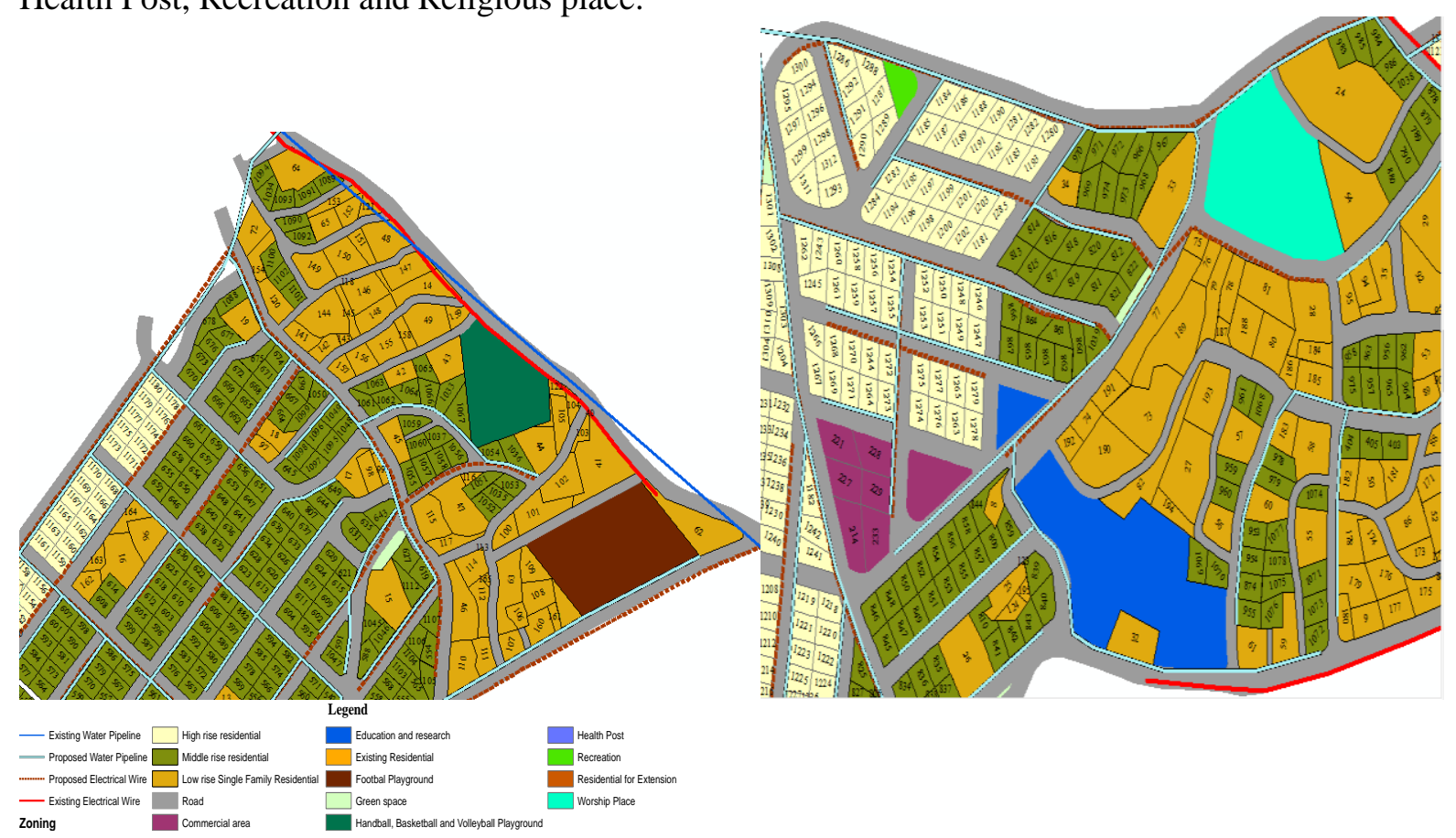

Figure 3. Sample on Layout plan of Kabeza Site

For housing developed in disorder will cause the problems of water supply and electrical distribution the reason why this project focused on dividing the available area in well-arranged and equal plots. This was achieved through participatory approach adopted by researchers. 
The total area of the site is 81.744 hectares, the existing plots are 445 according to the registered parcels from Rwanda Land Management and Use Authority. After planning and re-plotting, 213 Plots remain as they were before this project because they are already constructed and occupy a total area of 14 ha. For the new plots designed for residential area are 1096 plots with 33.98 ha say $42 \%$ of total area of Kabeza site. Some parts of the site are reserved for commercial and small market area with 1.24ha. Other parts are planned for green space with 0.97 ha say $0.19 \%$, for Recreational area with 1.58 ha, for health post with 0.5 ha. There is a part on the roads which is designed for road drainage and other with area of 640.66 square meter say 0.06 ha not passing along the road.

In general, after re-plotting, researchers found a total number of 1096 new plots for residential area and another for commercial area, education, health post, recreational area and green space.

From zoning requirements, 1096 plots have the size of $15 \mathrm{~m}$ width and $20 \mathrm{~m}$ of length say $(15 \mathrm{~m} * 20 \mathrm{~m})$. But due to the shape and some obstacles of existing buildings, all planned plots do not respect the 300 square meters. A smallest plot has 253 square meter and the maximum size of some plots is 398 square meter. The roads occupy a total length of $24.10 \mathrm{~km}$ with area of 29.20 ha around $31.66 \%$. Due to the topographic characteristic of the study area, this project discovered that there are zones which are not suitable for residential. All unfavorable areas for residences are located for green space and this land has 0.97 ha.

As planned by this project, plots with 300 square meter fit for single family residential for people requiring a house of 4 bedroom house and plus. ${ }^{9}$ Researchers proposed that 132.5 square meter be located for houses while the other portion of 167.5 square meter is designed for greening, parking, septic and water tank, land reserved for vegetables (known in Kinyarwanda as akarima k'icyikoni) and fence. These services are also among the required for a well-being of any family in Rwanda and some are recommended by law.

\section{CONCLUSION}

The preparation of detailed Physical planning for Kabeza Site, Kabeza Village, Kanzenze Cell and Ntarama Sector in Bugesera District, is based on consultations with stakeholders and planning parameters are taken into account. In addition to this, researchers adopted a participatory approach. Field information and topographic survey shown that the existing situation of houses and related services do not follow required standards. New designed plots indicate a great improvement as far as the existing living style of residents is concerned. Re-plotting took into consideration all surrounding infrastructures and waste disposal. Researchers suggest that the waste disposal area be located at least $6 \mathrm{~km}$ from residential area or be located at $5 \mathrm{~km}$ from area of Kabeza site. This will be facilitated by the use of daily transport of the waste to the dump area.

As revealed by this project, re-plotting of the concerned village produced total parcels of 1309 . These new plots represent residences where 908 plots are for single family residential and 188 Plots are for single family residential with one store while other 213 Plots remain as they are currently on the site. Other area of the site is designed for roads with $24 \mathrm{Km}$ of the length of 12 and $9 \mathrm{~m}$ of width, Commercial (Small market and off-core commercial area) with 1.24 ha, education and research with 1.13 ha, green space of 0.97 ha, health post with 0.5 ha, recreational area with 1.51 ha and five (5) existing houses are affected by the planned road. The project implementers and partners, particularly the local government units overseeing the project sites, should pay attention to the growing income disparity and the exclusion of the poorest from development process. Government should identify measures to minimize the interventions that impact negatively the life of well-being of the poor and women. This article could help policy makers to set the appropriate measures for minimizing negative impacts on the environment and approaches to boost the infrastructural development. It could also help other researchers in the time they are going to make their research on physical planning and its implementation using participation approach in different country.

5.Acknowledgment. Author thanks all peoples who are supporting him in different way for their support and effort in other to make well this paper. 


\section{REFERENCES}

[1] Don, G., Mark, D. \& Anselm, H. (2014). A New Zealand Strategy for Cadastre 2034(6845), Kuala Lumpur, Malaysia, retrieved from https://www.fig.net/resources/proceedings/fig_proceedings/fig2014/papers/ts05c/TS05C_grant_dyer_ et al 6845.pdf.

[2] Abebe, F. K. (2011). Modeling informal settlement growth in Dar es salaam, Tanzania (Unpublished master thesis). University of Twente, Eschede, pp1-6.

[3] Rwanda Housing Authority (RHA) (2010). Affordable Housing Development project Report, Kigali, pp3-16.

[4] Amanda, B . (2009). Ten geographic facts about Vancouver. Washington: British Columbia. pp 6-7.

[5] Aneesh, K. M. (2012). Urban master plans in Rajasthan. Management Research and Practice, 4(1), 31-44.

[6] Mahendra, S. (2011). Long-term plan for sustainable urban development, London, UK, pp1-20.

[7] Government of Chile (1996). Convention on Biological Diversity of June 10, 1992 ratified on March 18, 1995, Rio de Janeiro, pp2.

[8] Donald, C. S. (1972). Professional education in public works/environmental engineering. Chicago, American Public Works and Association. pp 15-17.

[9] Esri. (2011). GIS for urban and regional planning. New York: Esri. pp 6-9.

[10] Mabogunje, A. (2001). Foundations for Urban Development in Africa. Washington: The Cities Alliance, pp 9-10.

[11] FAO(2007).Community Development and Empowerment, retrieved from http://www.fao.org/3/a1346e/a1346e00.pdf.

[12] Final Report, Version 3 State wide Parcel Map Database Project (November 10, 2017), retrieved from https://doa.wi.gov/DIR/V3_Final_Report.pdf.

[13] International Federation for Surveyors (FIG) (2005). International standard for Physical plan published, Cairo, Egypt, pp3-9.

[14] Kicukiro Urban Development Master Plan (n.d), retrieved from http://www.masterplan2013.kigalicity.gov.rw/downloads/Docs/RWF1101_03_Kigali\%20City_Maste r\%20Plan\%20Report_03062013-s.pdf

[15] Williamson, I., Enemark, S.,Wallace, J. \& Rajabifard, A. (2010). Land Administration for Sustainable Development, Esri Press, 380 New York Street, Redlands, California, pp 8-375.

[16] City of Kigali (2018). Guidelines on Local Land Development plan , Kigali, pp1-13

[17] Ministry of Infrastructure (MININFRA) (2015). Ministerial order de termining urban planning and building regulations, Kigali, Pp54-56.

[18] Jha, A. K., Barenstein, J. D., Phelps, P. M., Pittet, D. \& Sena, S., (2010) A Handbook for reconstruction after disaster, Washington, DC : World Bank, retrieved from https://www.preventionweb.net/files/12229_gfdrr.pdf

[19] Ministry of Infrastructure (MININFRA) (2018). Ministerial order determining u $r$ b a $n$ planning and building regulations. Kigali, pp 87-89.

[20] Ministry of Infrastructure (MININFRA) (2012). Urbanization and rural settlement sector. Strategic plan 2012/13-17/18. Kigali, pp23-28.

[21] Office for Urbanization (2007). Heart of our city Master plan implementation strategies. Lethbridge: Office for Urbanization. pp 8-11.

[22] National Institute of Statistic Rwanda (NISR) (2014). Rwanda $4^{\text {th }}$ population and housing census. Kigali: NISR, pp 14-17.

[23] Rwanda Land Management and Use Authority (RLMUA) (2017). Rwanda National Land Use Planning Guidelines, retrieved from http://www.rlma.rw/uploads/media/LUP_Guidelines_Final_Published.pdf

[24] Government of Rwanda (2018). Urbanization and Rural Settlement Sector Strategic Plan, Kigali, retrieved 
http://www.rha.gov.rw/fileadmin/user_upload/Documents/Final_Urbanization_Sector_Strategic_Plan _131210_.pdf

[25] Fareea, S. \& Angioletta,V. (2005) Urban planning and design methods for sustainable development, Politecnico di Torino, Italy, retrieved https://pdfs.semanticscholar.org/af6a/2a721925e49a017e3f392860fd55f7a9a43b.pdf

[26] Rwanda Housing Authority (RHA) (2014). Assessing informal settlements in all provinces, Kigali, MININFRA. pp57-59.

[27] Saba, T. (2012). Urban planning implementation manual, Amsterdam, University of Amsterdam.pp79.

[28] Samuel, D.W. (2013). Spatial planning framework for urban development and management in jos metropolis Nigeria. Greater Manchester: University of Salford, retrieved from https://usir.salford.ac.uk/id/eprint/30802/1/Final_Thesis_January_2014_2.pdf

[29] Sietchiping, R. (2005). A Geographic Information Systems and Cellular Automata-Based Model of Informal Settlement. Melbourne: The University of Melbourne, Melbourne.

[30] UNCHS. (1995). Monitoring human settlements, abridged survey. Indicators Programme. Nairobi: United Nations Centre for Human, retrieved from https://minervaaccess.unimelb.edu.au/bitstream/handle/11343/38860/66047_00000592_01_Sietchiping.pdf?sequenc $\mathrm{e}=1 \&$ isAllowed $=\mathrm{y}$

[31] Word-Bank. (2007). Land use and physical planning. Planning Construction, 3(7), 111-112.

[32] http://www.taiwan921.lib.ntu.edu.tw/newpdf/WBCHAP07ENG.pdf

[33] http://physicalplanning.gov.dm/land-use-and-development/land-use-and-development-plans 